\title{
Optimization of Parameters Affecting Noodle Drying by Taguchi Method
}

\author{
Rana Başataç ${ }^{1}$, Zehra Gülten Yalçın ${ }^{2 *}$, Mustafa Dağ $\breve{~}^{3}$, and Ercan Aydoğmuş ${ }^{4}$
}

\begin{abstract}
${ }^{1}$ Karatekin University, Faculty of Engineering, Department of Chemical Engineering, Çankırı, Turkey, (ORCID: 0000-0001-9267-1423), ranabasatac@gmail.com ${ }^{2 *}$ Karatekin University, Faculty of Engineering, Department of Chemical Engineering, Çankırı, Turkey, (ORCID: 0000-0001-5460-289X), zaltin@karatekin.edu.tr ${ }^{3}$ Karatekin University, Faculty of Engineering, Department of Chemical Engineering, Çankırı, Turkey, (ORCID: 0000-0001-9540-3475), mudag@karatekin.edu.tr ${ }^{4}$ Firat University, Faculty of Engineering, Department of Chemical Engineering, Elazığ, Turkey, (ORCID: 0000-0002-1643-2487), ercanaydogmus@,firat.edu.tr
\end{abstract}

(2nd International Conference on Applied Engineering and Natural Sciences ICAENS 2022, March 10-13, 2022)

(DOI: 10.31590/ejosat.1063298)

ATIF/REFERENCE: Başataç R., Yalçın, Z. G., Dağ, M., \& Aydoğmuş, E. (2022). Optimization of Parameters Affecting Noodle Drying by Taguchi Method. European Journal of Science and Technology, (34), 34-41.

\begin{abstract}
In this research, Taguchi method application studies have been carried out to optimize the parameters affecting the drying of noodles made in Çankırı region by sun, conventional oven, and microwave method. In the experimental study, the noodles were dried in a single row in thin strips of 3-4 mm constant thickness to form an area of $100 \mathrm{~cm}^{2}$ (square plate). Variable parameters in three different drying methods are temperature, duration, and microwave power level. Sun drying of noodles was performed at an average temperature of 19 ${ }^{\circ} \mathrm{C}$ in June. Oven drying experiments were carried out at different temperatures $\left(75^{\circ} \mathrm{C}, 100{ }^{\circ} \mathrm{C}, 150{ }^{\circ} \mathrm{C}\right)$ and times $(30,60,90$ minutes $)$. Microwave drying operations were performed at $300 \mathrm{~W}, 450 \mathrm{~W}, 600 \mathrm{~W}$ power and 1, 2, 3 minutes respectively. The factors affecting the moisture content that can be separated from the noodles in the conventional oven were determined as drying temperature and drying time. In microwave drying, power and drying time were chosen as control factors. For this purpose, the L9 orthogonal sequence was arranged in Taguchi design used in experimental studies. The effects of control factors were determined by analyzing variance analysis (ANOVA) at 95-97.6\% confidence level. The study also analyzed moisture, ash, protein, color, and volume increase for dried noodles with 3 different drying techniques. In the sun drying of the noodles, 9.47 moisture, 1.33 ash, 10.73 protein, $87.48 \mathrm{~L} *$ color value, 1.03 $\hat{a}^{*}$ color value, $22.46 \mathrm{~B}^{*}$ color value, and 282.67 volume increase values were found. In the oven drying, 9.20 moisture, 1.31 ash, 10.77 protein, $80.24 \mathrm{~L}^{*}$ color value, $1.64 \hat{\mathrm{a}}^{*}$ color value, $24.10 \mathrm{~B} *$ color value, and 250.23 volume increase values were measured. 8.73 moisture, 1.29 ash, 10.83 protein, $78.50 \mathrm{~L} *$ color value, $0.90 \hat{a}^{*}$ color value, $25.13 \mathrm{~B} *$ color value, and 262.40 volume increase values were determined in the microwave drying.
\end{abstract}

Keywords: Noodles, Drying, Taguchi method, Variance analysis.

\section{Erişte Kurutmasını Etkileyen Parametrelerin Taguchi Metodu ile Optimizasyonu}

Öz

Bu çalışmada, Çankırı yöresinde yapılan eriştenin, güneşte, konvansiyonel firında ve mikrodalga yöntemi ile kurutulmasına etki eden parametrelerin optimizasyonun da Taguchi metodu uygulama çalışmaları yapılmıştır. Deneysel çalışmada, erişte 3-4 mm sabit kalınlıkta ince şeritler halinde $10 \mathrm{cmx} 10 \mathrm{~cm}$ 'lik bir alan oluşturacak şekilde tek sıra halinde kurutulmuştur. Üç farklı kurutma yönteminde değişken parametreler sıcaklık, süre ve mikrodalga da güç seviyesidir. Erişselerin güneşte kurutma işlemi Haziran ayı ortalaması bir sıcaklıkta $19{ }^{\circ} \mathrm{C}$ 'de gerçekleştirilmişken firında kurutma denemeleri; $75,100,150{ }^{\circ} \mathrm{C}$ sıcaklıkta, 30, 60, 90 dakikada, mikrodalgada kurutma işlemleri sırasıyla $300,450,600 \mathrm{~W}$ gücünde ve 1,2, 3 dakikalık sürelerde gerçekleştirilmiştir. Erişteden ayrılabilen nem oranını etkileyen kontrol faktörleri olarak konvansiyonel firında kurutmada kurutma sıcaklığı ve kurutma süresi, mikrodalga kurutmada ise güç ve kurutma süresi seçilmiştir. Bu amaçla deneysel çalışmalarda kullanılan Taguchi tasarımında L9 ortogonal dizi düzenlenmiştir. Kontrol faktörlerinin etkileri \% 95-97.6 güven seviyesinde varyans analizi (ANOVA) kullanılarak tespit edilmiştir. Bu çalışma sonucunda optimum erişte kuruma koşulları; firında kurutma için $150^{\circ} \mathrm{C}$ firın sıcaklığı ve 90 dakika kurutma süresi olarak belirlenmiş iken mikrodalgada kurutma için $600 \mathrm{~W}$ ssıtma gücü ve 3 dak kurutma süresi olarak tespit edilmiştir. Çalışmada ayrıca 3 farklı kurutma teknikleriyle kurutulmuş erişteler için nem, kül, protein, renk ve hacim artışı analizleri de yapılmıştır. Eriştelerin güneşte kurutulmasında 9.47 nem, 1.33 kül, 10.73 protein, $87.48 \mathrm{~L}^{*}$ renk değeri, $1.03 \mathrm{a}^{*}$ renk değeri, $22.46 \mathrm{~B}^{*}$ renk değeri ve 282.67 hacim artı̧̧ değerleri bulunmuştur. Firında kurutmada 9.20 nem, 1.31 kül, 10.77 protein, $80.24 \mathrm{~L}^{*}$ renk değeri, 1.64 â* renk değeri, $24.10 \mathrm{~B}^{*}$ renk değeri ve 250.23 hacim artış değerleri ölçülmüştür. Mikrodalga kurutmada 8.73 nem, 1.29 kül, 10.83 protein, $78.50 \mathrm{~L}^{*}$ renk değeri, 0.90 â* renk $^{*}$ değeri, 25.13 B* renk değeri ve 262.40 hacim artış değerleri belirlenmiştir.

Anahtar Kelimeler: Erişte, Kurutma, Taguchi yöntemi, Varyans analizi. 


\section{Introduction}

In our country, the use of noodles as a winter food with various ingredients is widely available. Noodles are prepared by kneading flour, salt, water, and egg; It is a preferred cereal product due to its vitamin and mineral substances, high energy due to carbohydrates, easy preparation, cheap cost, and taste [1]. In general, in addition to flour and eggs, it is also produced by diversifying by adding various vegetables and additives according to the regions where it is produced [2].

Noodles consumed as a traditional product receive different local names according to the way they are cut. When the dough is cut into large squares of $4 \times 4 \mathrm{~cm}$, it is called "Big Dough-Perişka", when cutting into small squares of $5 \mathrm{~mm} \times 5 \mathrm{~mm}$, "Tutmaç" for soup, and "Noodles" when cut into thin long strips of $4 \mathrm{~cm}$ dough (Fig. 1).

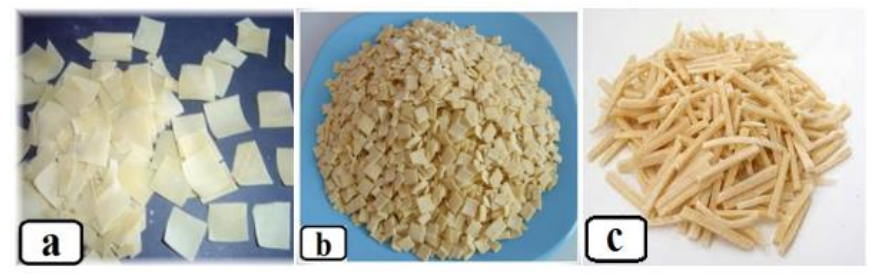

Fig. 1. Homemade pasta according to cutting shapes a) Coarse dough-Perişka b) Tutmaç c) Noodles [4]

It is a product obtained from dough prepared by adding wheat flour, salt, egg, and drinking water according to Turkish Standards Institute, Noodle Standard No. TS 12950 and dried following its technique. In this Standard, 3 types of noodles (plain, flavored, and enriched) are defined depending on the ingredients included in it [3]. The physical and chemical properties of noodles according to Turkish Standards Institute are given in Table 1.

Table 1. Turkish Standards Institute, physical, chemical, and microbiological properties of noodles [3]

\begin{tabular}{lccc}
\hline \multicolumn{1}{c}{ Features } & \multicolumn{3}{c}{ Amount } \\
\hline & $\begin{array}{c}\text { Plain } \\
\text { Noodles }\end{array}$ & $\begin{array}{c}\text { Seasoned } \\
\text { Noodles }\end{array}$ & $\begin{array}{l}\text { Enriched } \\
\text { Noodles }\end{array}$ \\
\hline $\begin{array}{l}\text { Total Ash \% } \\
\text { max. }\end{array}$ & 1.0 & 1.5 & 1.0 \\
$\begin{array}{l}\text { Moisture } \% \\
\text { max. }\end{array}$ & 13.0 & 13.0 & 13.0 \\
$\begin{array}{l}\text { Salt \% max. } \\
\text { Protein \% at } \\
\text { least }\end{array}$ & 2.0 & 2.0 & 2.0 \\
$\begin{array}{l}\text { Substance } \\
\text { Passing } \\
\text { Water \% max. }\end{array}$ & 10.5 & 10.5 & 10.5 \\
\hline $\begin{array}{l}\text { It should be white-creamy, white in color tones, with a } \\
\text { unique odor, taste, and appearance. }\end{array}$
\end{tabular}

Noodles are suitable for enrichment studies because it is food product prepared in a short time with a few easy-to-find ingredients and simple methods. For this reason, various cereals, legumes, vegetable, and fruit flours were added to the noodle dough and the quality criteria, nutritional contents, and changes in functional properties were examined. There are studies in which a product with high nutritional value and functional properties has been developed by adding chestnut flour in various proportions to the noodle formulation [4].
There are studies that noodles and similar products can be produced to enrich the diet of celiac patients who are sensitive to gluten and similar proteins. In the studies conducted for this purpose, it was emphasized that rice and corn can be used as gluten-free products, and the importance of using stabilizers due to structural necessity was emphasized [5].

In another study, chickpea flour was added to noodles and couscous at different rates to improve nutritional, technological, and sensory properties. In this study, it was concluded that a product enriched with $30 \%$ chickpea flour solid and suitable from a technological and sensory point of view could be obtained. It has been noted that the nutritional value of noodles increases with the addition of eggs in noodles, its cooking properties improve, and there are positive improvements in color [6].

In the study of Erbay and Küçüköner, the diversity of the ingredients added to the noodle and their effects on the product quality were investigated, and different seasonings were produced to develop a new product. Here, a product has been developed that can be consumed with noodles with popular tastes [7].

A study comparing the physical and chemical properties of various noodle samples produced in Izmir was conducted by Güllü and Karagöz. In this study, it was stated that the changes in quality criteria were caused by differences in the raw materials and production technologies used [8].

The purpose of the drying process is to increase the shelf life of the product by reducing the amount of water in the food by between $10 \%$ and $20 \%$. Thus, microbiological degradation and enzyme activity in food are reduced, storage and shelf life are extended, storage and shipment become easier [9].

Conventional drying, vacuum drying, infrared ray drying, osmotic drying, freeze-drying, and microwave drying methods are used in the drying of foods [10]. The researchers said that the physical and chemical content, rehydration ability, initial and final moisture values of the product to be dried should be very well known at the decision-making stage for the drying method.

Some studies indicate that microwave drying is successfully used in a 3-step process (pre-drying with hot air-drying with microwave-balancing) in the study where microwave drying is used in the pasta industry [11- 12].

The advantages and disadvantages of drying in the sun, oven, and microwave in the process of drying many products in the food industry have been studied [13].

The researchers noted that the advantage of microwave drying is to heat the product more evenly and homogeneously, while the disadvantage is that the initial investment cost is high. In addition, they pointed out that the chemical composition of the product, product dimensions, the air temperature of drying, and the airspeed of drying is important to the drying speed.

In drying experiments, it is seen that the high-cost drying time is effective in determining the quality characteristics. At the same time, the fact that there are some difficulties in the results of multiple experimental studies and verification makes it necessary to carry out preliminary design studies. For this reason, it is mandatory to carry out experimental studies with preliminary design, product quality improvement, and minimum cost in the experimental study. One of these used methods is the Taguchi method. The Taguchi method is considered to be an effective method used in recent industrial studies to obtain products and at the same time obtain low-cost products. In the analysis, 
orthogonal series and ANOVA methods are used. ANOVA helps to study the influence of factors on characteristic features. The most important advantage of the Taguchi method over traditional statistical methods is that it plays an effective role in determining experimental working conditions that have the least diversity in optimal working conditions $[8,14,15]$.

In another research, there is a study on the effect of the addition of different grain flours and mixing ratios in the production of gluten-free spaghetti using the Taguchi method [16]. However, it was found that the study in which the noodles were dried and the experimental parameters were optimized by the Taguchi method did not exist.

This study aims to investigate the drying behavior of noodles consumed in Çankırı region, which are drying methods; solar, household oven, and microwave, and to determine the optimum drying conditions using the experimental design method Taguchi modeling. In the drying studies, when solar, conventional oven, and microwave drying methods were compared, it was seen that the fastest drying was achieved by microwave drying and the slowest drying was solar drying. In addition, when explaining the effect of drying methods, the change of physical and chemical properties of samples prepared for noodles was compared. It was found that the changes in moisture, ash, and protein contents were insignificant in noodles dried by three different drying methods, and the changes in color values and volume increase by the applied drying methods changed significantly.

\section{Material and Method}

Before the drying process, all samples were kept at $105^{\circ} \mathrm{C}$ for 24 hours in the Sartorius MA150 model moisture determination test and weighed after the test. The moisture content was found as by the formula in Eq. 1.

Protein analysis of noodle samples was performed using the calibrated Foss Infratec 1241 Grain Analyzer to measure pasta values.

The ash values of all dried samples were measured by Simsek Laborteknik Ash Furnace KF-908 at $900{ }^{\circ} \mathrm{C}$ for 4 hours. using the Hunter color scale. For this purpose, $\mathrm{L}^{*}, \mathrm{a}^{*}$, and $\mathrm{b}^{*}$ values were determined with Konica Minolta CR410 device. The L* (lightness) value on the Hunter color scale represents brightness or opacity/opacity. $\mathrm{L}^{*}$ takes values between $0-100.0$ means completely glossy and 100 means completely matte (black). $a^{*}$ and $b^{*}$ can take negative or positive values. Negative values of $a^{*}$ represent shades of green, while positive values represent shades of red. The negative values of $b^{*}$ represent the hue of the blue color, while the positive values represent the hues of the yellow color.

In cooking experiments, volume increases were measured by studying according to TS 1620 standard [20].

Wheat flour obtained from the UNTAŞ flour factory, which is produced in Çankırı, was used for the noodle dough. The dough, which was prepared by hand as a hard dough with $2 \mathrm{~kg}$ of wheat flour, 4 eggs, 1 L of water, $60 \mathrm{~g}$ of finely ground Çankırı rock salt and rested for approximately 30 minutes, was rolled out to 3-4 $\mathrm{mm}$ thick first with a rolling pin and then with a rolling pin. After waiting for 2 hours at room temperature to allow the dough to gather itself and reach the consistency to be cut, the samples to be used in the trial phase were cut into long strips with a width of 3$4 \mathrm{~mm}$ with a bread knife and stored in a $4{ }^{\circ} \mathrm{C}$ refrigerator until analyzed in clean bags. Before the experiments, the dough strips
The color parameters of the noodle samples were made numerical

were cut with a knife of 3-4 mm thickness to be thin and long, and the drying process was carried out by arranging them in a single row covering an area of $10 \times 10 \mathrm{~cm}$ on oiled paper. In noodles, 3-4 $\mathrm{mm}$ was used as a fixed thickness because the doughtiness occurred in the baking process of the final product by increasing the thickness.

In this study, Taguchi modeling was performed without the thickness parameter because the dough thickness could not be changed in noodle experiments. In this study, controllable factors and levels for noodles are given in Table 2. In a 2-parameter 3level structure, an orthogonal array and 9-experiment modeling were used and the experimental conditions prepared according to this orthogonal array are given in Table 3. The moisture losses of the samples were observed with the measurements taken as a result of the experiments. The regression equation, which will provide the optimum conditions, was obtained by modeling with the obtained data.

Table 2. Parameters and level values for noodles Oven Drying

\begin{tabular}{cc} 
Temperature $\left({ }^{\circ} \mathrm{C}\right)$ & Time $(\mathrm{min})$ \\
\hline 150 & 90 \\
100 & 60 \\
75 & 30 \\
\hline \multicolumn{2}{c}{ Microwave Drying } \\
Power $(\mathrm{W})$ & Time (min) \\
\hline 600 & 3 \\
450 & 2 \\
300 & 1 \\
\hline
\end{tabular}

Table 3. Experimental conditions were prepared with an orthogonal array for noodles

\begin{tabular}{ccc}
\hline \multicolumn{3}{c}{ Microwave Drying } \\
\cline { 2 - 3 } Experiment No. & Power $(\mathrm{W})$ & Time $(\mathrm{min})$ \\
\hline 1 & 600 & 3 \\
2 & 600 & 2 \\
3 & 600 & 1 \\
4 & 450 & 3 \\
5 & 450 & 2 \\
6 & 450 & 1 \\
7 & 300 & 3 \\
8 & 300 & 2 \\
9 & 300 & 1 \\
\hline & Oven Drying & \\
Experiment & Temperature $\left({ }^{\circ} \mathrm{C}\right)$ & Time $(\mathrm{min})$ \\
\hline 1 & 150 & 90 \\
2 & 150 & 60 \\
3 & 150 & 30 \\
4 & 100 & 90 \\
5 & 100 & 60 \\
6 & 100 & 30 \\
7 & 75 & 90
\end{tabular}




\begin{tabular}{rrr}
8 & 75 & 60 \\
9 & 75 & 30 \\
\hline
\end{tabular}

The noodle dough was cut into thin strips of 3-4 mm thickness and left to dry in the shade by arranging them in a single row to form an area of 10x10 $\mathrm{cm}$. To determine the moisture loss and separable moisture content (ANO), the samples were weighed every 6 hours.

Conventional oven drying trials at $75{ }^{\circ} \mathrm{C}, 100{ }^{\circ} \mathrm{C}$, and $150{ }^{\circ} \mathrm{C}$. It was made with Beko BSUF 5000 MGSI model oven with adjustable fan support. The internal temperature of the oven is adjusted with a digital temperature meter.

To create the drying curves, the weights were taken at 15 minute intervals at the determined temperatures. A drying timemoisture loss graph was drawn.

To compose the drying curves, weighing was taken at the determined temperatures at 30-minute intervals. Noodles were dried using the Samsung MS23F301 EAW household microwave (at power levels of $300 \mathrm{~W}, 450 \mathrm{~W}$, and $600 \mathrm{~W}$ ). A drying timemoisture loss graph was composed. Since the dough thickness of the noodles could not be changed, measurements depending on the thickness were not taken.

Drying experiments in the sun were carried out in the shade in June when the air temperature was $19^{\circ} \mathrm{C}$ compared to the longterm average during the summer period [17]. Microwave drying experiments were carried out with a modified Samsung MS23F301 EAW brand and model microwave that can operate at 3 power levels.

The moisture content of the samples used in the drying experiments was calculated using Eq. 1. The initial moisture content of the samples prepared with Equation 3 and the moisture content lost by drying was calculated. The "Removable Moisture Ratio" (ANO) in Eq. 2 shows the amount of removable moisture in the product at a certain " $t$ " time, it is a dimensionless value. ANO helps to determine the required time for the same material to reach the moisture or desired moisture value at certain times in environments similar to trial conditions. Equilibrium moisture content is the amount of water contained in the air under drying conditions and is measured with a hygrometer and is neglected in many studies because it is a very small value. The drying rate of the samples was calculated using Equation 3 (19).

$$
M=100 \cdot M w /(M w+m d)
$$

$M=$ Moisture content (\%), based on wet

$M w=$ amount of water $(\mathrm{g})$,

$m d=$ amount of dry matter $(\mathrm{g})$

$$
A N O=(M 1-M e) /(M 0-M e)
$$

$A N O=$ Separable moisture,

$M 1=$ amount of water at any time ( $\mathrm{kg}$ water $/ \mathrm{kg}$ dry matter),

$M O=$ Amount of water before starting drying ( $\mathrm{kg}$ water $/ \mathrm{kg}$ dry matter),

$M e=$ Equilibrium moisture content of the dried product (neglected)
$D R=[(M 1+d t)-M 1] / d t$

$D R=$ Drying rate $(\mathrm{kg}$ water $/ \mathrm{kg}$ dry matter $)$

$M 1=$ Amount of water at any time (kg water $/ \mathrm{kg}$ dry matter),

$M 1+d t=$ Amount of water after sequential measurement $(\mathrm{kg}$ water/kg dry matter),

$d t=$ Time between consecutive measurements (min.)

For statistical analysis and Taguchi Modeling, the package computer statistical program Minitab 17.0 was used. Variance Analysis techniques were applied to the data obtained from the samples. The mean values of the sources of variation, the differences of which were found to be statistically significant, were explained by the Tukey test in $5 \%$ confidence interval. In the statistical analyses mentioned below, mean square root deviation (RMSE) and chi-square tests were applied to experimental and theoretical models. In these equations, the number of experiments $(N)$ and the number of parameters in the model $(n)$ is shown.

$R M S E=\sqrt{\sum_{i=1}^{N}\left(\frac{\text { ANO }_{\text {experiment }_{i}}-A N O_{\text {theoretical }_{i}}}{N}\right)^{2}}$

$K i-$ Square $=\sum_{i=1}^{N}\left(\frac{\text { ANO }_{\text {experiment }_{i}}-\text { ANO }_{\text {theoretical }_{i}}}{N}\right)^{2}$

In this study, parameters affecting experimental drying (oven temperature, time, and microwave power) were used. Optimization study was done with Taguchi method. Taguchi design is one of the experimental design methods developed to design experiments where many factors and levels affect the results and to find the factors that affect them. This method, it is aimed to minimize the effects of uncontrollable factors in the use of orthogonal arrays that focus on improving the output of a process. In the Taguchi method, first of all, the so-called degree of freedom (SD) data is collected and the orthogonal array is selected for the total degree of freedom (TSD).

In this study, 3 determination levels were selected for the 2 parameters used. The total degrees of freedom of the parameters used were found by subtracting 1 from the levels of the parameters. In addition, by adding the value of 4 , which is "Residual error", a total of 8 degrees of freedom were obtained for 3 levels of 2 parameters. (Table 1). The data used in the Taguchi L9 orthogonal index for the level of drying experiments are shown in Table 2. The result of the study is given by converting it to $\mathrm{S} / \mathrm{N}$ (signal/noise) ratio in the Taguchi method. The signal-to-noise ratio is used to control the results obtained in the experimental study and to reduce the variability according to the results.

In Taguchi method used, there are three performance evaluations for the $\mathrm{S} / \mathrm{N}$ ratio: minimum (smaller-the better), maximum (larger-the-better), and average (nominal-the-best). In this study, functions including maximum (drying temperature and microwave power) and minimum (moisture content) Separable moisture values were determined. Eq. 6 and Eq. 7 are used for maximum and minimum performance values [24]. Where $n$ for the number of tests and $y i$ for the performance characteristics is the number of observed experimental data [21]. 
$\frac{s}{N_{\max }}=-10 \log \left(\frac{1}{n} \sum_{i=1}^{n} \frac{1}{y_{i}^{2}}\right)$

$$
\frac{s}{N_{\min }}=-10 \log \left(\frac{1}{n} \sum_{i=1}^{n} y_{i}^{2}\right)
$$

\section{Results and Discussion}

Table 4. Drying parameters and levels were used in the study

\begin{tabular}{|c|c|c|c|c|c|c|c|}
\hline \multicolumn{2}{|l|}{ Parameter } & SD & \multicolumn{2}{|c|}{ Level 1} & \multicolumn{2}{|c|}{ Level 2} & Level 3 \\
\hline \multicolumn{2}{|c|}{ Temperature $\left({ }^{\circ} \mathrm{C}\right)$} & 2 & \multicolumn{2}{|l|}{75} & \multicolumn{2}{|c|}{100} & 150 \\
\hline \multicolumn{2}{|l|}{ Time (min.) } & 2 & \multicolumn{2}{|l|}{30} & \multicolumn{2}{|l|}{60} & 90 \\
\hline Total SD & & 8 & & & & & \\
\hline Parameter & $\mathrm{SD}$ & Level & & Lev & 12 & Lev & 13 \\
\hline Power (W) & 2 & 600 & & 450 & & 300 & \\
\hline Time (min.) & 2 & 3 & & 2 & & 1 & \\
\hline Total SD & 8 & & & & & & \\
\hline
\end{tabular}

Moisture losses of noodles related to drying under the sun at an average temperature of $19{ }^{\circ} \mathrm{C}$ in June are shown in Figure 2. At the end of 24 hours, it was determined that the decrease in the amount of moisture in the sample reached 0.30. It is seen that the decrease in moisture specified in the TS 12950 Noodle standard is rapidly reached within the first 6 hours, and the decrease in moisture slows down in 12-24 hours' period.

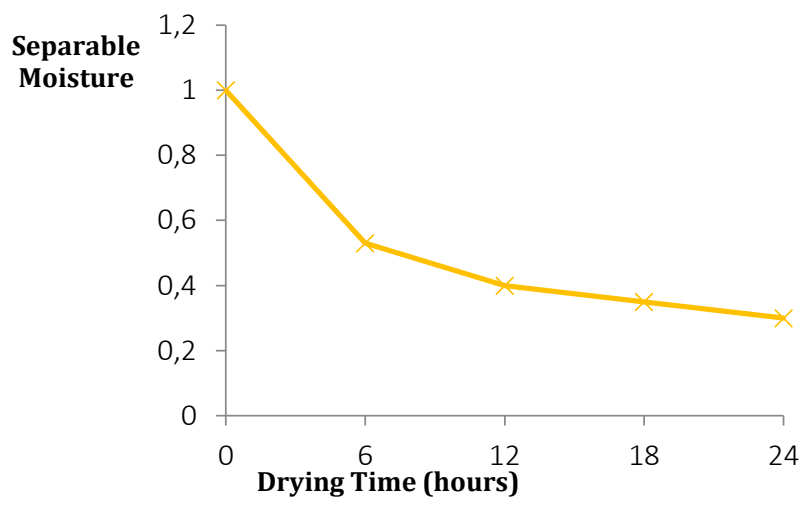

Fig. 2. Moisture change graph for noodles in sun drying

Studies were carried out at $75{ }^{\circ} \mathrm{C}, 100{ }^{\circ} \mathrm{C}$, and $150{ }^{\circ} \mathrm{C}$ for drying in a fan oven. The moisture was removed in the noodles at 30, 60, 90 minutes as the drying time was plotted (Figure 3). When drying in the oven, it is seen that drying takes place in a short time as the temperature increases. Drying at $150^{\circ} \mathrm{C}$ at the highest temperature $90 \mathrm{~min}$. occurs rapidly and the moisture value removed approaches 0.09 (Table 5). It has been determined that the drying time is extended up to 180 minutes at the lowest value where the oven temperature is $75^{\circ} \mathrm{C}$. It was observed that the decrease in the moisture rate was low during the trial periods.

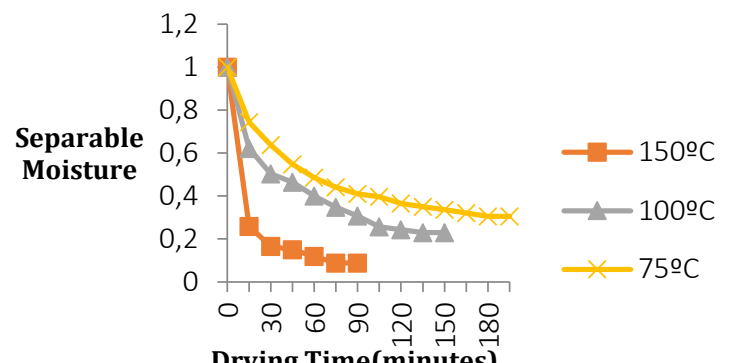

Drying Time(minutes)

\section{Figure 3. Moisture change in the oven drying for noodles}

In the modified microwave drying study, it is seen that drying takes place up to 7 minutes at 5 different power levels $(300,450$, 600,700 , and 800 Watt) (Figure 4). In the study carried out with $700,800,300,450,600 \mathrm{~W}$ by Taguchi methods. Moisture contents vary depending on the microwave power level, and at the highest $600 \mathrm{~W}$ power level, the moisture content drops rapidly in 4 minutes, thus drying is fast and approaching zero. 7 minutes drying at low $300 \mathrm{~W}$ power level. It lasts for a long time, and the removal of moisture is slow [18-19]. In short, as the microwave power level increases, the drying time of the product decreases.

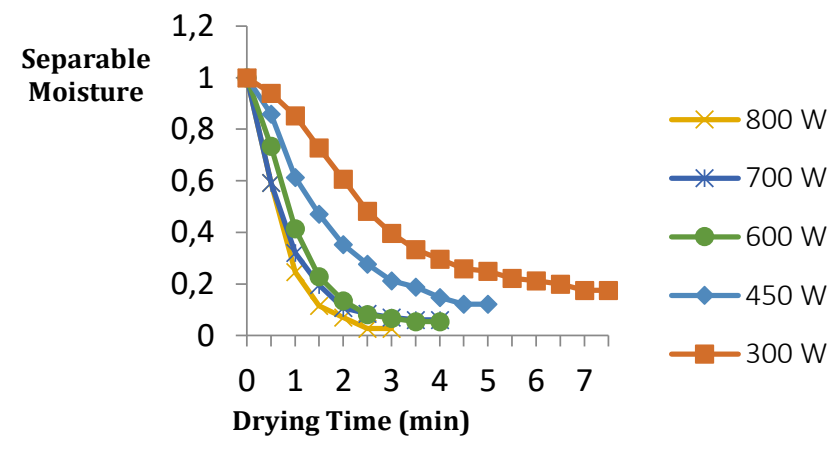

Figure 4. Moisture change in microwave drying for noodles

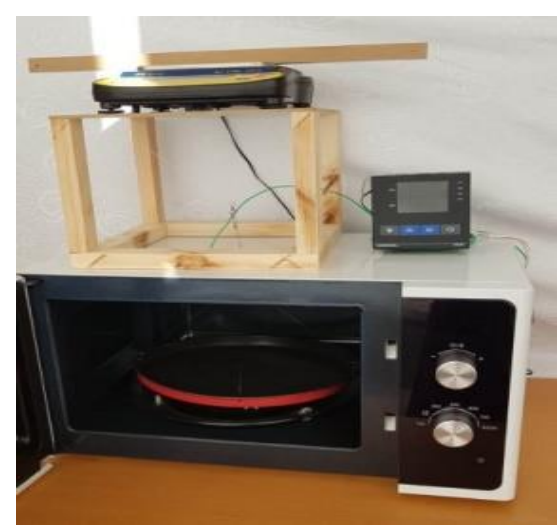

Figure 5. Modified microwave drying assembly

Moisture changes of the experiments determined by Taguchi modeling are given in Tables 5 and 6 and Figures 6 and 7 in terms of separable moisture content (ANO). Here, calculations were made by choosing smaller is better as the signal-to-noise ratio. When the analysis of variance technique was applied to the data obtained in the drying experiment in the conventional oven, it was observed that the statistical $\mathrm{P}$ values for all factors (temperature and time) were in the low range $(\mathrm{p}<0.001)$. The variance analysis technique used by Canyılmaz and Kutay was also found to be 
effective in our study [13]. When the data for oven drying were examined, it was determined that the modeling was statistically within the $95.6 \%$ confidence interval $(p<0.001)$. It is seen that the temperature $(\mathrm{p}<0.001)$ and time $(\mathrm{p}<0.017)$ parameters are statistically effective on drying. The regression equation obtained as a result of the modeling is shown in Equation 8.

Table 5. Taguchi modeling of values obtained in oven drying

\begin{tabular}{llll}
\hline \multicolumn{3}{c}{ Oven Drying } \\
\hline $\begin{array}{l}\text { Experiment } \\
\text { No. }\end{array}$ & $\begin{array}{l}\text { Temperature } \\
\mathbf{C}^{\circ} \mathbf{C} \text { ) }\end{array}$ & $\begin{array}{l}\text { Time } \\
\text { (min) }\end{array}$ & $\begin{array}{l}\text { Separable } \\
\text { moisture }\end{array}$ \\
\hline 1 & & 90 & 0,09 \\
2 & 150 & 60 & 0,12 \\
3 & 150 & 30 & 0,17 \\
4 & 150 & 90 & 0,31 \\
5 & 100 & 60 & 0,40 \\
6 & 100 & 30 & 0,50 \\
7 & 100 & 90 & 0,41 \\
8 & 75 & 60 & 0,49 \\
9 & 75 & 30 & 0,64 \\
\hline
\end{tabular}

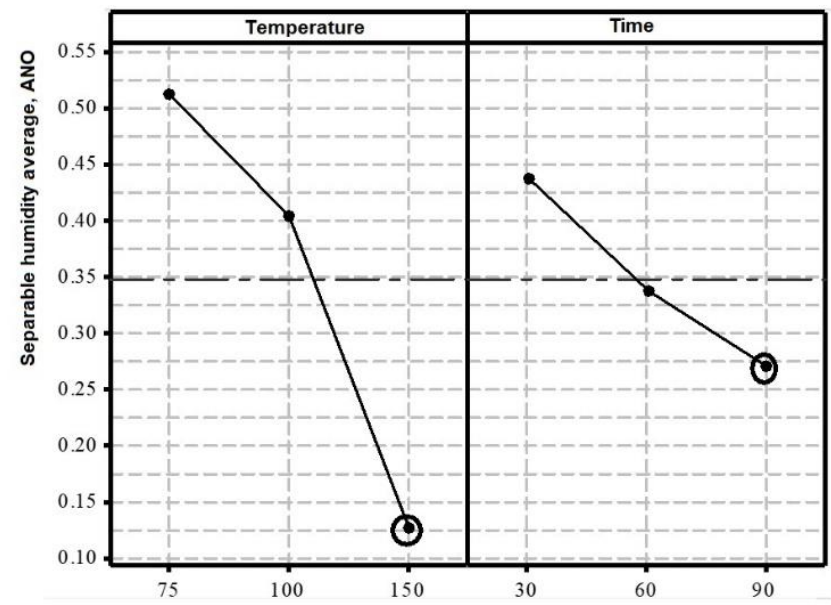

Fig. 6. Main effect for ANO average in oven drying values

Seperable Moisture $=1.0788-0.005210 \mathrm{~T}-0.002778 \mathrm{t}$

When the analysis of variance technique of drying experiments in a microwave oven was applied, it was observed that statistically, $\mathrm{P}$ values for all factors (power and time) were in the low range $(p<0.001)$. When the data for microwave drying were examined, it was seen that the modeling was statistically within the $97.6 \%$ confidence interval $(\mathrm{p}<0.001)$. Power $(\mathrm{p}<0.001)$ and time $(p<0.001)$ parameters were found to be statistically effective on drying. Eq. 9 is obtained as a result of the analysis of the data.

Table 6. Taguchi modeling of values obtained in microwave drying experiments

\begin{tabular}{cccc}
\hline \multicolumn{4}{c}{ Microwave drying } \\
\hline $\begin{array}{c}\text { Experiment } \\
\text { No. }\end{array}$ & Power (W) & $\begin{array}{c}\text { Time } \\
\text { (min) }\end{array}$ & $\begin{array}{c}\text { Separable } \\
\text { moisture }\end{array}$ \\
\hline 1 & 600 & 3 & 0.07 \\
2 & 600 & 2 & 0.13 \\
3 & 600 & 1 & 0.41 \\
4 & 450 & 3 & 0.21 \\
5 & 450 & 2 & 0.35
\end{tabular}

\begin{tabular}{llll}
6 & 450 & 1 & 0.61 \\
7 & 300 & 3 & 0.40 \\
8 & 300 & 2 & 0.61 \\
9 & 300 & 1 & 0.85 \\
\hline
\end{tabular}

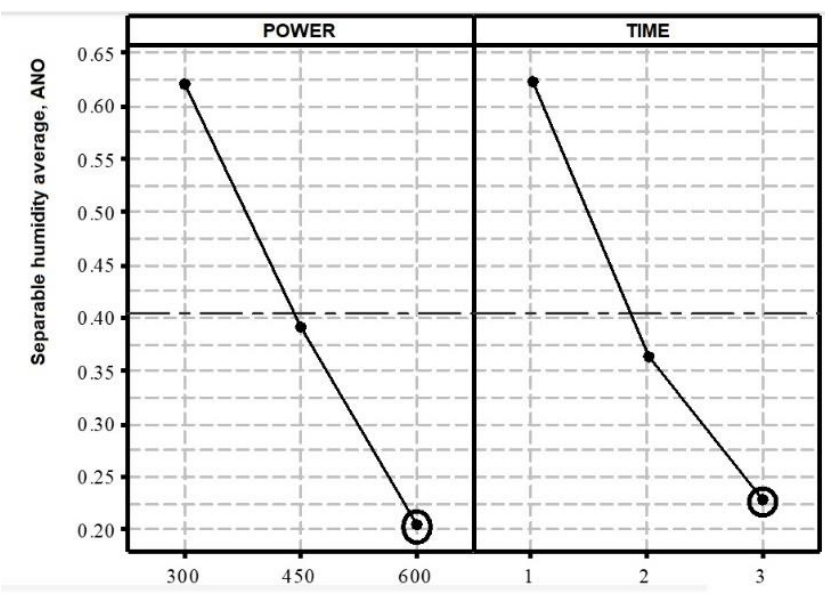

Fig. 7. Main effect for ANO average in the microwave drying

Seperable Moisture $=1.4261-0.1983 t-0.001389$

When Taguchi modeling is examined; It was observed that $\mathrm{R}^{2}=0.956$ for conventional oven drying and $\mathrm{R}^{2}=0.976$ for microwave drying. When these two methods are compared with each other, the difference is very low. While the best drying condition for the oven was determined as $150^{\circ} \mathrm{C}$ oven temperature and 90 minutes drying time, $600 \mathrm{~W}$ heating power, and 3 minutes drying time were determined for microwave drying.

In this study, the moisture content of the noodle should be maximum $13 \%$ according to TS 12950 . The moisture rates obtained in all methods are suitable for this content. When analyzed statistically by linear regression analysis in the Minitab program, it was seen that the moisture content of the samples changed insignificantly $(\mathrm{p}>0.05)$ depending on the drying methods. In this study, it was observed that all three methods were successful in terms of moisture content removal. Drying was achieved in a short time with the microwave drying method.

In this study, 9 different experimental studies and 3 re-runs were calculated, 27 different moisture values were tested with the Minitab 18 program. After that, ANOVA analyzes were performed with the Taguchi method (Table 7).

Table 7. Moisture content and calculated $S / N$ ratio for the furnace drying process

\begin{tabular}{ccccccc}
\hline Temperature & Time & $\begin{array}{c}\text { ANO } \\
\text { Experimental }\end{array}$ & $\begin{array}{c}\text { S/N Ratio } \\
\text { Experimental }\end{array}$ & $\begin{array}{c}\text { ANO } \\
\text { Predictive }\end{array}$ & $\begin{array}{c}\text { S/N Ratio } \\
\text { Predictive }\end{array}$ & $\begin{array}{c}\text { ANO } \\
\text { Residual }\end{array}$ \\
\hline 150 & 90 & 0.09 & 20.91 & 0.04 & 20.44 & 0.04 \\
150 & 60 & 0.12 & 18.41 & 0.11 & 18.35 & 0.01 \\
150 & 30 & 0.17 & 15.39 & 0.21 & 15.92 & -0.04 \\
100 & 90 & 0.31 & 10.17 & 0.32 & 10.25 & -0.01 \\
100 & 60 & 0.4 & 7.95 & 0.39 & 8.16 & 0.01 \\
100 & 30 & 0.5 & 6.02 & 0.49 & 5.73 & 0.01 \\
75 & 90 & 0.41 & 7.74 & 0.43 & 8.13 & -0.02 \\
75 & 60 & 0.49 & 6.19 & 0.50 & 6.05 & -0.01 \\
75 & 30 & 0.64 & 3.87 & 0.60 & 3.62 & 0.03 \\
\hline
\end{tabular}


$\mathrm{S} / \mathrm{N}$ ratios are observed with the moisture value obtained as a result of drying times of 30, 60, 90 minutes in oven drying. The ratio $\mathrm{S} / \mathrm{N}$ with the largest average gives the smallest moisture value. According to the average $\mathrm{S} / \mathrm{N}$ ratio value given in Figure 67 , the smallest optimum moisture content is $150{ }^{\circ} \mathrm{C}$, where the largest average $\mathrm{S} / \mathrm{N}$ ratios are obtained, $90 \mathrm{~min}$. It was obtained in the oven drying experiment, where the reduced moisture was 0.09 . While the average $\mathrm{S} / \mathrm{N}$ ratio also increases with the oven temperature. It is observed that the average $\mathrm{S} / \mathrm{N}$ value decreases with the ANO value (Table 7).

Table 8. Moisture content and calculated $S / N$ ratio for the microwave drying process

\begin{tabular}{ccccccc}
\hline Power & Time & $\begin{array}{c}\text { ANO } \\
\text { Experimental }\end{array}$ & $\begin{array}{c}\text { S/N Ratio } \\
\text { Experimental }\end{array}$ & $\begin{array}{c}\text { ANO } \\
\text { Predictive }\end{array}$ & $\begin{array}{c}\text { S/N Ratio } \\
\text { Predictive }\end{array}$ & $\begin{array}{c}\text { ANO } \\
\text { Residual }\end{array}$ \\
\hline 600 & 3 & 0.07 & 23.09 & 0.025 & 21.14 & 0.04 \\
600 & 2 & 0.13 & 17.72 & 0.16 & 16.65 & -0.03 \\
600 & 1 & 0.41 & 7.74 & 0.42 & 10.76 & -0.01 \\
450 & 3 & 0.21 & 13.55 & 0.21 & 13.94 & -0.01 \\
450 & 2 & 0.35 & 9.11 & 0.34 & 9.45 & 0.001 \\
450 & 1 & 0.61 & 4.29 & 0.60 & 3.56 & 0.001 \\
300 & 3 & 0.4 & 7.95 & 0.44 & 9.51 & -0.04 \\
300 & 2 & 0.61 & 4.29 & 0.57 & 5.02 & 0.031 \\
300 & 1 & 0.85 & 1.41 & 0.83 & -0.87 & 0.01 \\
\hline
\end{tabular}

In microwave drying, the experimental conditions with $600 \mathrm{~W}$ heating power and 3 min drying time (slowest drying speed) were obtained as 0.07 , as seen in Table 8 . Table 8 shows that the $\mathrm{S} / \mathrm{N}$ ratio is lower at $300 \mathrm{~W}$ microwave power. Experimental and estimated $\mathrm{S} / \mathrm{N}$ ratios are given in the Taguchi assessment. In addition, it is seen that there is faster moisture removal in $450 \mathrm{~W}$ power than $300 \mathrm{~W}$ power. By drying the noodles in the microwave; It was determined that the drying time decreased as the microwave power increased. In short, as the microwave power increased, the drying time of the product gave similar results with the studies in the literature [18-19].

ANOVA, where the effect of the experimental parameter on the study is given as a percentage, also shows the importance of the results obtained in terms of statistical studies, in which they are frequently applied [22]. In the experimental study, ANOVA method was applied by using $\mathrm{S} / \mathrm{N}$ ratios to determine the parameters and effect values that affect drying [23]. The most important parameter in the drying process is the temperature in oven drying and Watt, which is the power of the device in microwave drying. It is seen that the average $\mathrm{S} / \mathrm{N}$ ratio increases with microwave power and the average $\mathrm{S} / \mathrm{N}$ value decrease with the ANO value (Table 8). Moisture, ash, protein, color changes, and volume increases in Hunter color scale obtained after all three drying methods of noodles were determined (Table 7).

Table 9. Physical and chemical analysis results for noodles

\begin{tabular}{|c|c|c|c|c|c|c|c|}
\hline \multicolumn{8}{|c|}{ Noodle } \\
\hline & $\begin{array}{c}\text { Moisture } \\
\%\end{array}$ & Ash \% & $\begin{array}{l}\text { Protein } \\
\%\end{array}$ & $L^{*}$ & $\begin{array}{c}\text { Color } \\
a^{*}\end{array}$ & $b^{*}$ & $\begin{array}{c}\text { Volume } \\
\text { Increase \% }\end{array}$ \\
\hline $\begin{array}{l}\text { Sun } \\
\text { Drying }\end{array}$ & $\begin{array}{c}9.47 \pm 0,15 \\
3^{\mathrm{a}}\end{array}$ & $\begin{array}{c}1.33 \pm 0,0 \\
87^{\mathrm{a}}\end{array}$ & $\begin{array}{c}10.73 \pm 0,9 \\
50^{\mathrm{a}}\end{array}$ & $\begin{array}{c}87.48 \pm 0,2 \\
35^{\mathrm{a}}\end{array}$ & $\begin{array}{c}1.03 \pm 0,0 \\
20^{\mathrm{a}}\end{array}$ & $\begin{array}{c}22.46 \pm 0,1 \\
45^{\mathrm{a}}\end{array}$ & $\begin{array}{c}282.67 \pm 3,1 \\
50^{\mathrm{a}}\end{array}$ \\
\hline $\begin{array}{l}\text { Oven } \\
\text { Drying }\end{array}$ & $\begin{array}{c}9.20 \pm 0,36 \\
1^{\mathrm{ab}}\end{array}$ & $\begin{array}{c}1.31 \pm 0,0 \\
35^{\mathrm{a}}\end{array}$ & $\begin{array}{c}10.77 \pm 0,5 \\
69^{\mathrm{a}}\end{array}$ & $\begin{array}{c}80.24 \pm 0,3 \\
29^{\mathrm{b}}\end{array}$ & $\begin{array}{c}1.64 \pm 0,1 \\
33^{\mathrm{b}}\end{array}$ & $\begin{array}{c}25.13 \pm 0,6 \\
21^{\mathrm{a}}\end{array}$ & $\begin{array}{c}262.40 \pm 2,1 \\
00^{\mathrm{b}}\end{array}$ \\
\hline
\end{tabular}



The drying behavior of noodles was investigated in 3 different drying methods. Drying in the conventional oven $\left(75^{\circ} \mathrm{C}, 100^{\circ} \mathrm{C}\right.$, and $\left.150{ }^{\circ} \mathrm{C}\right)$, microwave oven $(300 \mathrm{~W}, 450 \mathrm{~W}, 600 \mathrm{~W})$ and sun drying were carried out at an average of $19{ }^{\circ} \mathrm{C}$ in June. Taguchi modeling experiments were carried out as an optimization study during the experiments. The results obtained are summarized below.

It has been found that by drying the noodles in a conventional oven, the drying time changes with temperature, and the drying time decreases as the temperature increases. The drying process of noodles in the sun was carried out at a temperature of $19^{\circ} \mathrm{C}$ in June, while the oven drying experiments were carried out at a temperature of $75,100,150{ }^{\circ} \mathrm{C}$ in $30,60,90$ minutes. Drying temperature and drying time in conventional oven drying and power and drying time in microwave drying were selected as control factors affecting the moisture that can be separated from noodles. For this purpose, the L9 orthogonal array was arranged in the Taguchi design used in experimental studies. The effects of control factors were found to be at a $95 \%$ confidence level.

By drying the noodles in the microwave; It was determined that the drying time decreased as the microwave power increased. Drying processes in the microwave were carried out at $300 \mathrm{~W}, 450$ $\mathrm{W}, 600 \mathrm{~W}$ power, and for 1, 2, 3 minutes, respectively. Power and drying time were selected as control factors affecting the moisture content that can be separated from the noodle in microwave drying. For this purpose, the L9 orthogonal array was arranged in the Taguchi design used in experimental studies. The effects of control factors were found to be at the $97.6 \%$ confidence level. In short, as the microwave power increased, the drying time of the product decreased.

When the speed graphs are examined, it is seen that the drying speed for oven drying is low and the drying speed for microwave drying is quite high. When the Analysis of Variance Technique was applied to the drying experiments performed in the conventional oven and microwave, it was observed that the $\mathrm{P}$ values were statistically significant $(p<0.001)$ for all factors (temperature and time).

Optimum conditions were determined in oven and microwave drying methods with Taguchi modeling for noodles. It has been determined that the best drying conditions are $150{ }^{\circ} \mathrm{C}-90 \mathrm{~min}$ for the oven and $600 \mathrm{~W}-3 \mathrm{~min}$. for the microwave. The study of Baynal and Gencel on the use of the Taguchi method in the food industry was also effective in determining the optimum conditions in our study.

The physical and chemical properties of noodle samples prepared under optimum conditions were compared. In this study, the targeted moisture content was achieved by three drying methods. Similar results were obtained in terms of ash and protein content. When evaluated in terms of color, it was found that the lightest color values were observed with sun drying, while the color turned orange when oven drying. The same result was obtained in the study conducted by Kemahlığlu and Demirağ. The highest value as a volume increase was achieved by solar drying, while the lowest value was obtained by microwave drying. 
Statistically, it was found that the change in moisture, ash, protein content in noodles was insignificant $(\mathrm{p}>0.05)$, and the changes in color values and volume increase were significant $(\mathrm{p}<0.001)$. It has been explained statistically that the difference in drying methods does not cause a change in moisture ash and protein values; it causes a large number of changes in volume increase and color value. In short, it has been observed that the drying method chosen for noodles affects volume increase and color.

When solar drying, conventional oven drying, and microwave drying methods were compared, it was seen that the fastest drying was achieved by microwave drying and the slowest drying was solar drying. It has also been observed that the drying rate for the microwave is much higher than the drying rate for the oven. In explaining the effect of drying methods, the physical and chemical properties of the samples prepared for noodles were compared. It was found that the changes in moisture, ash, and protein content in noodles were insignificant ( $p>0.05)$, and the changes in color values and volume increase with the applied drying methods changed significantly $(\mathrm{p}<0.05)$.

To save time and energy, it is necessary to accurately determine the drying process in a short time in terms of the optimum oven temperature and microwave power. In our study, the effects of temperature-power, duration relationships on drying for conventional oven and microwave in noodles were examined. It was determined that the initial moisture of the product was successfully reduced to the desired values in the constant thickness of oven drying and microwave drying methods for noodles.

The moisture content is required to be a maximum of $13 \%$ according to TS 12950 . In this study, appropriate results were obtained for the desired moisture values in all three methods. It was found that the best drying was achieved by microwave drying with a moisture content of $8.73 \%$, and the least drying was achieved by solar drying with a moisture content of $9.47 \%$. In this study, it was observed that it was successful in removing moisture content by three methods. When examined from a statistical point of view, it is observed that the changes in the moisture content of the samples depending on the drying methods are insignificant $(\mathrm{p}>0.05)$.

\section{Conclusions and Recommendations}

Optimum conditions are data that can be used to determine the relationships between temperature product thickness and drying speed and the time used to measure drying time, especially in industrial production. In our study, the noodle thickness was considered to be constant 3-4 mm. This thickness is preferred in Çankırı in terms of production and consumption. In addition, cracking or pulping occurred after drying in thinner or thicker selected samples.

It was found that the oven drying method (95.6\%) was successful in choosing the optimal product made by Taguchi modeling, and the microwave drying method (97.34\%) was successful. Considering the success of Taguchi modeling in the oven drying method; It has been concluded that optimum conditions can be achieved by providing the correlation between the lowest number of experiments (9) and temperature-timemicrowave power changes.

Optimum conditions for oven drying have been successfully determined using Taguchi modeling with a constant thickness (3$4 \mathrm{~mm}$ ) of noodles. As a result of this study, the optimum noodle e-ISSN: 2148-2683 drying conditions were determined as $150{ }^{\circ} \mathrm{C}$ oven temperature and 90 min drying time for oven drying, while $600 \mathrm{~W}$ heating power and 3 minutes drying time were determined for microwave drying.

\section{References}

Y. Ertaş, and M. G. Karadağ, Să̆glıll beslenmede Türk mutfak kültürünün yeri, Gümüşhane Üniversitesi Sağlık Bilimleri Dergisi, 2(1), 117-136, 2013.

M. Mete, and D. D. Altıner, Eriştenin farklı un katkıları ile zenginleştirilmesi, Akademik G1da, 16(2), 252-256, 2018.

Türk Standartları Enstitüsü. Erişte Standart, TS 1295, Ankara, Türkiye, 2003.

M. Mete, Kestane Unu Katkısının Eriştenin Bazı Besinsel ve Kalite Özelliklerine Etkisinin Incelenmesi, Yüksek Lisans Tezi, İstanbul Aydın Üniversitesi Fen Bilimleri Enstitüsü, İstanbul, Türkiye, 2016.

S. Yalçın, and A. Başman, Glütensiz makarna ve erişte üretimi, 9. Gida Kongresi, Bolu, Türkiye, 2006.

B. Demir, Nohut Ununun Geleneksel Erişte ve Kuskus Üretiminde Kullanım Imkânları Üzerine Bir Araştırma, Yüksek Lisans Tezi, Selçuk Üniversitesi Fen Bilimleri Enstitüsü, Konya, Türkiye, 2008.

B. Erbay, and E. Küçüköner, Gıda endüstrisinde kullanılan farklı kurutma sistemler, 10. Gida Kongresi, Erzurum, Türkiye, 2008.

M. Güllü, and Ş. Karagöz, Geleneksel gastronomik ürün geliştirilmesi meyveli, sebzeli ve otlu erişte, International West Asıa Congress of Tourısm Research, Van, Türkiye, 2018.

K. Kemahlıŏlu, and K. Demirağ, Izmir'de tüketime sunulan çeşitli firmalara ait erişte ve makarna ürünlerinin bazı kimyasal ve fiziksel kalite nitelikleri, Akademik G1da, 16, 6066, 2018.

Ü. İ. Konak, M. Certel, and S. Helhel, Gida sanayisinde mikrodalga uygulamalar, Gida Teknolojileri Elektronik Dergisi, 4(3), 20-31, 2009.

K. M. Knutson, E. H. Marth, and M. Wagner, Microwave heating of food. LWT Food Science and Technology, 20, 101-110, 1987.

N. Kutlu, A. İşçi, and Ö. Ş. Demirkol Gıdalarda ince tabaka kurutma modelleri, G1da, 40(1), 39-46, 2015.

E. Canıy1lmaz, F. Kutay, Taguchi metodunda varyans analizine alternatif bir yaklaşım, Gazi Üniversitesi Mühendislik ve Mimarlık Fakültesi Dergisi, 18(3), 51-63, 2003.

K. Baynal K, and İ. Gencel, Taguchi yönteminin gıda sektöründe çok yanıtl problemin en iyilemesinde uygulanması, Sakarya Üniversitesi Fen Bilimleri Enstitüsü Dergisi, 19(1),107-121, 2015.

N. K. I. Mayasti, M. Ushada, and M. Ainuri, Optimization of gluten free spaghetti products from local food with the taguchi method approach, IOP Conference Series: Earth and Environmental Science, 251, 2019.

Meteoroloji Genel Müdürlüğü, Web Sitesi. https://www.mgm.gov.tr, Erişim Tarihi: 03.09.2019.

M. Sarı, and S. Karaaslan, Ananasın mikrodalga ile kurutulması ve uygun kuruma modelinin belirlenmesi, Süleyman Demirel Üniversitesi Ziraat Fakültesi Dergisi, 9(1), 42-50, 2014.

S. Karaaslan. Trabzon hurmasının mikrodalga ile kurutulmasında uygun kuruma modelinin belirlenmesi, Süleyman Demirel Ünversitesi Ziraat Fakültesi Dergisi, 9(1), 8-15, 2014. 